\title{
DEFINING RURAL AREAS OF VISEGRAD COUNTRIES
}

\section{Ladislav NOVOTNÝ ${ }^{1} \bullet$ Vladan HRUŠKA ${ }^{2} \bullet T^{2}$ Táás EGEDY ${ }^{3} \bullet$ Marcin MAZUR $^{4}$}

${ }^{1}$ Pavol Jozef Šafárik University in Košice, Faculty of Science Department of Geography, Jesenná 5, 040 01, Košice, Slovakia ladislav.novotny@upjs.sk

2Jan Evangelista Purkyně University in Ústí nad Labem, Faculty of Science Department of Geography, České mládeže 8, 400 96, Ústí nad Labem, Czechia vladan.hruska@ujep.cz

${ }^{3}$ Research Centre for Astronomy and Earth Sciences, Hungarian Academy of Sciences Geographical Institute, Budaörsi str. 45, H-1112, Budapest, Hungary egedy@gmx.net

${ }^{4}$ Institute of Geography and Spatial Organization, Polish Academy of Sciences Twarda 51/55, 00-818 Warsaw, Poland m.mazur@twarda.pan.pl

\begin{abstract}
The article is focused on the introduction and categorization of various approaches to rurality, and the identification and delimitation of rural areas in Visegrad countries. Three substantively different groups of conceptualizations and definitions of rural and rurality are described as follows: functional definitions, rural as locality (political-economic approaches), and social representation. Latter, basic sorts of methods and approaches to the delimitation of rural areas in V4 countries are introduced emphasizing its historical development, differences in spatial level and criteria of delimitation in current research. Due to different nature of rural areas and even local administrative units (the basic units usually used for delimitation of rural areas), it is not possible to reach sufficient and reliable identification of rural areas for whole $V 4$ area using any of criteria or definitions applied in the research at national levels. Therefore, the average population density of entire V4 area was used as a main criterion for distinguishing between urban and rural LAU 2 at the whole Visegrad area level. Such approach is also affected by generalization but it captures various conditions in each country relatively well and moreover, it is comparable with the OECD and European Union methods to some extent.
\end{abstract}

Key-words: rurality, rural areas, Visegrad countries, population density, local administrative units.

\section{Introduction}

Rurality and peripherality are topics very often discussed in the research of geographers, economists, sociologists and representatives of many other scientific fields, which makes these terms conspicuous. However, it has also created a huge inconsistency and ambiguity in their perception and interpretation. This occurs among researchers from different disciplines as well as among individual researchers from different countries, research 
institutes or even within them. In some approaches the meaning of rural incorporates what some other approaches define as peripheral, regardless whether the periphery is identified in a rural or urban area. On the other hand, some approaches consider rurality as a condition of peripherality. Such conceptual ambiguity often worsens the clarity of research and causes misunderstanding in the interpretation of results.

Whereas the definitions of rural and rurality themselves sometimes also include the spatial aspect of peripheral position to urban cores, emphasis is put on approaches to rural and rurality first, and then, in the article by Novotný, Mazur, Egedy (2015), to peripherality in its various interpretations. At the beginning of this article, different approaches to the interpretation of rurality are presented and subsequently, some examples of delimitation and classification of rural areas in Visegrad countries are introduced.

\section{Approaches to rural and rurality}

The definition of objects, people, places and area which are considered as rural could be approached from various points of view. There have been many attempts to classify diverse conceptualizations of rural (see e.g. Halfacree 1993; Woods 2005; Cloke 2006; Hruška 2014a). In this part of the article we will focus on those definitions which could be regarded as the most relevant for further reaserch.

\section{Functional definitions}

Functional definitions of rural (in line with Cloke 2006) are based on one of the oldest and most important binary relations used both in academic and everyday discourse - the relation between urban and rural (Woods 2011: 3). Rural space is from this point of view defined by the following three functional elements (Cloke 2006: 20):

- dominance of extensive land use (mostly by agriculture and forestry),

- small settlements which are formed by buildings with a strong relationship to extensive landscape and which are considered as rural by most of their residents,

- a way of life which is characterized by a cohesive identity based on environmental and behavioural qualities.

The first two functional elements typically represented by the population size of the settlement for example, are very often used as a tool for defining rural and urban areas, as they have observable and therefore also quantifiable character (Halfacree 1993). Since the 1950s rural areas have been increasingly penetrated by urban influences due to the counterurbanization process (especially in Western Europe and Northern America) and the general endeavour of national governments to modernise rural areas. As a result, the functional definition appears to be insufficient and the model of urban-rural continuum was used as a reaction to the blurring of the border between rural and urban. However, even this model has failed to describe the complexity of the urban-rural intersection (Woods 2005).

\section{Rural as a locality}

The definition of rural based on political-economic approaches, which introduced the concept of locality, marked an important breakthrough in rural studies. The definition of rural as a locality conditioned rejection of both urban-rural dichotomy and urban-rural continuum concepts. Such a definition aims to define rural areas per se, not as the oppo- 
site to urban. Moreover, locality concept allows their relative openness, because localities could be defined as an area, which is constituted by actors and their groups or by a network of relations which transcend various scales and distances. Hereby, a broad range of connections with different influences form a particular locality (Murdoch and Marsden 1994). Accordingly, rural should be constructed by specific social, economic and political processes which determine its rurality. Nevertheless, both Hoggart (1990) and Halfacree (1993) are sceptical whether such defining processes exist. Therefore, the existence of rural localities as a specific combination of local processes was rejected (Cloke 2006: 21). There are no social, economic and political processes influencing both rural and urban areas, which would be specific to just one of them. Instead, rural and urban localities are the result of various constellations of local, regional or even global processes. Therefore rural areas are fully part of the national or transnational political economy.

On the other hand, some of these processes could be manifested differently in urban and rural areas - for example providing public services (public transportation; energy, gas and water supplies etc.) in rural areas is more difficult and costly than in densely inhabited areas (Moseley 1980: 27). From this point of view the definition of rural as locality is very promising, as it is necessary to consider which influences do the key characteristics of rural areas (especially small settlements and extensive land use resulting in low population density) have on the political economy of rural areas. Regarding the economy or entrepreneurship in rural areas, the paper by Smallbone (2005) is very relevant. He focuses on the implications of rural milieu for entrepreneurship. Apart from the rural distinctiveness which is discussed in the next section, he analyses it from the following points of view:

- the small size of local markets - this is clearly the most important barrier for the economic development of rural areas. The small size of the local market is due to low population density, and also to lower per capita incomes in some, mostly peripheral, rural areas.

- Rural labour characteristics - rural labour markets are very often of small size, narrow occupational composition and lower levels of educational attainment. Therefore access to skilled labour could be very problematic and could hinder the growth of rural firms. Reflecting on this fact, it is necessary to say that many economic activities in rural areas do not require a highly skilled labour force. Nevertheless, with the growing service sector in both rural and national economies this could impose a constraint on rural economic development.

- The availability of business premises - generally in rural areas business premises may be less available than in urban areas, despite their lower price. Moreover, the offer of business premises could be significantly limited in cases where a particular rural locality is part of an area under environmental protection. Nevertheless, in the case of the post-socialist countries, especially in those where collectivization of agriculture caused almost complete depeasantization (Czechia, Slovakia), there are many available premises of former "sovkhozes" or "kolkhozes" which could be used for new economic activities (naturally after consolidation of property rights and their renovation).

- Transport and communication infrastructure and access to information, advice, finance and business services - the remoteness from main centres or markets is a significant constraint for further growth of rural businesses. On the other hand, significant improvements in the transportation infrastructure and technologies 
have brought about a fall in costs and have improved the accessibility of many peripheral rural areas. Similarly, the development of ICT has lowered the dependence on commuting to city centres and enabled internet-based homeworking. Despite this positive development it must be noted that due to the sparse population, some rural areas are not completely covered by broadband internet or mobile phone coverage.

\section{Rural as social representation}

The conceptualization of rural as a locality has not defined what is rural. As was mentioned above, within political-economic approaches, rural as a specifically delimited category of space does not exist, since there are no processes which could define it. Cloke and Goodwin (1992) agree with this statement. However, inspired by Mormont (1990) they contend that "Nevertheless, people such as, let's say, entrepreneurs, residents and leisure-seekers, continue to make decisions with reference to some imagined concept of 'rural', thereby attributing behavioural validity to a concept of rurality which relies on the social production of meanings" (Cloke and Goodwin 1992: 321-322). According to these authors, the importance of the word "rural", apart from its material dimension, consists also in its imaginary dimension. So if there is something rural, then it exists in our ideas not in the material space. As such, rural as social representation is defined as an organizational mental construction which helps us to respond to what is visible. Therefore, the importance of rural is situated in social, cultural and moral values which are related to rurality, rural space and rural life (Cloke 2006: 21).

Behavioural validity of the concept of rural as a social representation has significant consequences also for rural economies/entrepreneurship. If we continue with the very useful analysis by Smallbone (2005), in this section the following points should be discussed:

- Rural distinctiveness - some of the owners of small rural enterprises manage their businesses according to what could be called rural socio-cultural values. To be more specific, they put stress on their "word of mouth" reputation and on the primacy of relations with their family, relatives and friends. Other studies (e.g. Bosworth 2012) have discovered a strong feeling of responsibility of business owners derived from the strong embeddedness of their businesses in the community.

- The institutional environment - is determined by the behaviour of local actors and institutions which influence entrepreneurship in rural localities. Such factors are especially important in post-socialist countries where the rate of entrepreneurship is lower as a consequence of four decades of state paternalism. Regarding this fact, the positive role of counterurbanisers, attracted to rural localities by the better price of real estate, environment and perceived rural idyll, should be emphasized. Their higher qualifications, income and entrepreneurial experience gained in urban centres increase the economic performance of rural localities, especially those located in proximity to urban centres. 


\section{Basic methods and approaches to the delimitation of rural areas in Visegrad countries}

The delimitation of rural regions is determined by the definition of rurality itself. And as aforementioned, definitions of what is rural and rurality are ambiguous and vary among various countries, various scientific fields, various approaches and even various researchers.

Pioneers of rural geography in Visegrad countries already focused in the 1960s on the definition, transformation and typification of rural areas. The first attempts to define rural areas (i.e. villages) appeared in Hungary during the 1960s (Beluszky 1965) and during the 1970s statistical data were already used to delimit rural areas (Enyedi 1977). In the same decade the first major works on settlement geography, ethnography, social geography and rural sociology were also published in Poland and Czechoslovakia (Kiełczewska-Zaleska 1972; Erdei 1974; Barta et al. 1975; Lettrich 1976; Kostrowicki 1976; Kulcsár 1976; Szulc 1976). In the early 1980s Beluszky and Sikos (1983) applied factor and cluster analysis involving 28 variables for the identification of rural areas in Hungary. Generally, a common feature of the research in all Visegrad countries from the 1960s till the 1980s was the avoidance of defining a 'rural space' and the focus on the classification of rural settlements by social, economic, functional issues, and agriculture as its key phenomenon.

The concept of rurality and the problem of rural space moved, in the 1990s, beyond the boundaries of the villages and the first attempts were made to also integrate the surroundings of settlements into the definition of rural areas. Since then, many attempts to identify and classify rural space were made in Visegrad countries considering a more or less wide range of indicators and statistical data, some of them emphasizing the strong relation between the concept of rurality and broadly perceived peripherality. Over the past one and a half decades research has focused more on the classification of micro-regions instead of the exact delineation of rural areas, which was an important issue for enforcing the national, regional and rural development policies. It was also important from another point of view, namely, the micro-regional level (LAU 1) became the determinative level of regional planning and interventions in the first decade of the 2000s. From the beginning of the 2000s, research on "rural development areas" came to the fore since the accession of Visegrad countries into the European Union called for an EU-conformity definition of rural areas also at micro-regional level (see Kovács et al. 2015). Although methodology in the classification of regions in respect of its rurality developed by the OECD ${ }^{1}$ and also used by the European Commission has often been incorporated recently into the practice of all Visegrad countries, there are frequent approaches reflecting the uniqueness of settlement, communal and regional structures in each country. Selected approaches are presented in Table 1.

In comparison with other Visegrad countries, in Czechia the population limit for delimitation of rural municipalities is the lowest $-3,000$ inhabitants. This threshold is based

${ }^{1}$ Basic OECD regional typology is applied only to the level of NUTS III regions and is based on criteria of population density and size of the urban centres located within a region. It is made of three main steps: a. Classifying units (LAU2) as rural if their population density is below $150 \mathrm{inhab} . / \mathrm{km}^{2}$. b. Aggregating these units into the NUTS III region and classifying these regions as predominantly urban, if the share of population living in rural units is below 15\%, Intermediate, if it is between 15 and $50 \%$ and Predominantly rural if it is more than $50 \%$. c. If the region classified as predominantly rural includes an urban centre with more than 200,000 ihabitants it changes into intermediate. similarly, if classified as intermediate and it contains an urban centre with more than 500,000 inhabitants it changes into predominantly urban (OECD 2011). 
Table 1. Examples of descriptive definitions of rural areas in Visegrad countries

\begin{tabular}{|c|c|c|c|}
\hline Country & Spatial level & Categories \& criteria & Source \\
\hline Czechia & $\begin{array}{l}\text { municipalities } \\
(\text { LAU 2) }\end{array}$ & municipalities with less than 3,000 inhabitants & $\begin{array}{l}\text { The Municipal Act } \\
\text { (No. 128/2000 Coll.) }\end{array}$ \\
\hline Hungary & $\begin{array}{l}\text { municipalities } \\
(\text { LAU 2) }\end{array}$ & $\begin{array}{l}\text { rural municipalities - without town status and less than } \\
10,000 \text { inhabitants }\end{array}$ & Dorgai (1998) \\
\hline Hungary & $\begin{array}{l}\text { micro-regions } \\
(\text { LAU 1) }\end{array}$ & $\begin{array}{l}\text { rural micro-regions (subcategories - average developed } \\
\text { and disadvantaged) - factor and cluster analysis conside- } \\
\text { ring ratio of active earners in agriculture, Golden Crown } \\
\text { value }{ }^{2} \text {, rurality index (population density below } 120 \text { inha- } \\
\text { bitants } / \mathrm{km}^{2} \text { ) and migration (average annual rate) }\end{array}$ & Csatári (2000, 2005) \\
\hline Hungary & $\begin{array}{l}\text { micro-regions } \\
(\text { LAU 1) }\end{array}$ & $\begin{array}{l}\text { predominantly rural (population density up to } 120 \text { inh./ } \\
\mathrm{km}^{2} \text { ), rural with urban centres (population density up to } \\
120 \mathrm{inh} . / \mathrm{km}^{2} \text { and urban centre with more than } 20,000 \\
\text { inh.), urban (pop. density over } 120 \mathrm{inh} . / \mathrm{km}^{2} \text { ) }\end{array}$ & NHRDP (2007) \\
\hline Poland & $\begin{array}{l}\text { municipalities } \\
(\text { LAU 2) }\end{array}$ & $\begin{array}{l}\text { non-urban administrative category or less than } 5,000 \text { inh. } \\
\text { (rural areas: } 94.2 \% \text { of total area, } 42.1 \% \text { of total population }\end{array}$ & MRRW (2014) \\
\hline Poland & $\begin{array}{l}\text { municipalities } \\
\text { (LAU 2) }\end{array}$ & $\begin{array}{l}\text { non-urban administrative category or less than } 10,000 \\
\text { inh. (rural areas: } 95.1 \% \text { of total area, } 45.4 \% \text { of total } \\
\text { population) }\end{array}$ & Bański (2015) \\
\hline Slovakia & $\begin{array}{l}\text { districts } \\
(\mathrm{LA \cup} 1)\end{array}$ & $\begin{array}{l}\text { rural (population density up to } 100 \mathrm{inh} . / \mathrm{km}^{2} \text { ), intermedia- } \\
\text { te }\left(100-350 \mathrm{inh} . / \mathrm{km}^{2}\right) \text {, urban (over } 350 \mathrm{inh} . / \mathrm{km}^{2} \text { ) }\end{array}$ & $\begin{array}{l}\text { Fáziková et al. } \\
\text { (2003) }\end{array}$ \\
\hline Slovakia & $\begin{array}{l}\text { municipalities } \\
(\text { LAU 2) }\end{array}$ & municipalities with less than 5,000 inhabitants ${ }^{3}$ & Act 369/1990 Coll. \\
\hline
\end{tabular}

Source: own compilation by authors.

on the Municipalities Act which allows the granting of town status only to a municipality with at least 3,000 inhabitants. Such a low threshold value is derived from the administrative structure of Czechia, as on the lowest level (LAU 2) there are 6,253 self-governing municipalities whose average population (about 1,680 inhabitants) and area (12.6 km²) is very low in comparison with Poland's $(15,530)$ and Hungary's $(3,130)$ municipalities. It is even lower than the average population size in communities in Slovakia $(1,870)$, where Act 369/1990 Coll. requires a community to reach at least 5,000 inhabitants to obtain town status. While in Czechia and Slovakia the number of inhabitants plays a key role in distinguishing between rural and urban communities also in law, in Hungarian and Polish law it plays only a minor role. However, in respect to the higher average population size of the communities and attributes used in the delimitation of rural areas by Dorgai (1998) in Hungary and by Bański (2015) in Poland, it is possible to accept a limit of 10,000 inhabitants for both countries.

Taking into account population size limits of 3,000 inhabitants for Czechia, 5,000 inhabitants for Slovakia and 10,000 inhabitants for Poland ${ }^{4}$ and Hungary, classification presented in Figure 1 was conducted for the whole Visegrad area.

${ }^{2}$ Golden Crown is the unit used for land evaluation in Hungary.

3 Slovak law considers each community to be rural unless it has obtained town status. The number of inhabitants is only one of the conditions to obtain that status and it does not necessarily have to be respected, but as it is the only easily quantifiable and verifiable condition it is often used for international comparisons.

${ }^{4}$ As there is plenty of LAU 2 in Poland consisting of many typically rural settlements together exceeding 10,000 inhabitants, only those LAU 2 which include a settlement with town status are considered to be urban. 


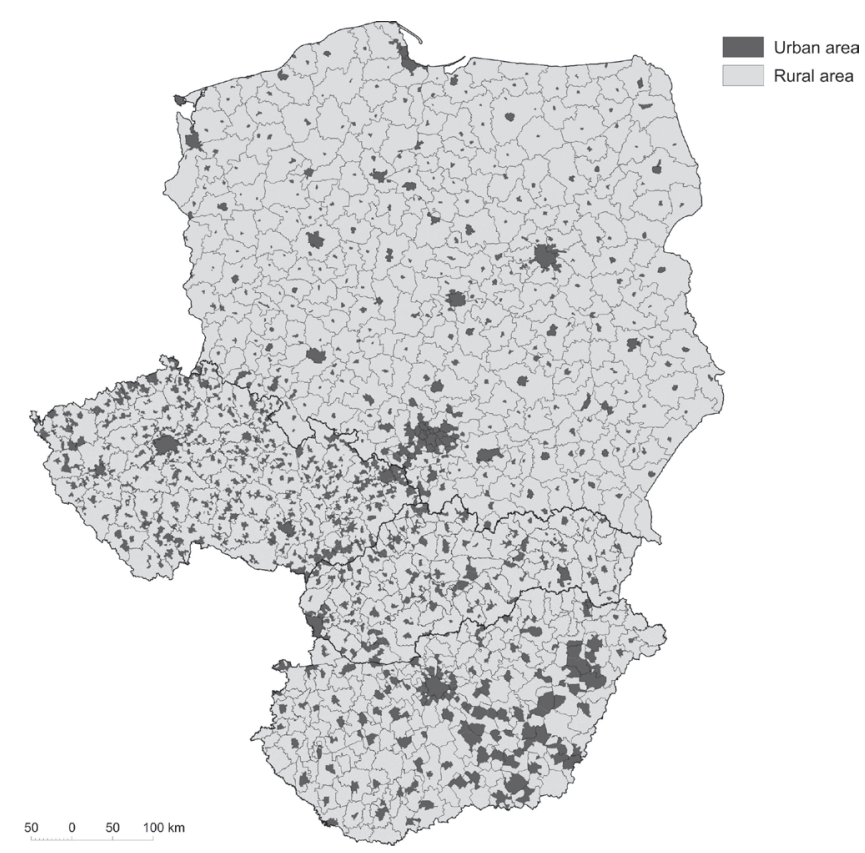

Fig. 1. Urban and rural LAU 2 in Visegrad countries by the number of inhabitants (see the criteria in the text above) Source: designed by M. Mazur.

Another standard frequently used in the delimitation of rural areas is population density. This is rather used at LAU 1 or NUTS III level, as it is in the OECD methodology (OECD 2011) which is also often used in documents and planning strategies within the European Union, but might also be applied at the LAU 2 spatial level. As shown by Figure 2, differences in population density among the regions are significant but at the level of countries as whole differences are much lower.

When taking mean population density in the whole Visegrad area as a criterion for distinguishing rural and urban LAU 2, the resulting picture is much different than the one respecting number of inhabitants. It seems to be much less dependent on the nature of LAU 2 in each country (Fig. 3). The advantage of this approach is that many densely populated suburban areas are, in contrast to population size criterion (Fig. 2), classified as urban. Similarly, the densely populated Upper Silesian basin is not included among rural areas.

Geographers of Visegrad countries have recently also focused on the approaches to classifying rural areas considering their specifics and processes taking place there, rather than the mere identification of rural areas. National Rural Strategy 2012-2020 in Hungary (MRD 2012) focuses on the specific categories of rural areas (at the level of LAU 2). When considering the settlement hierarchy, small villages (with a population of fewer than 1000 inhabitants) and farms (tanya) should be mentioned, because they are currently struggling with the greatest social and economic problems. Typical areas of the rural periphery appear in the north-eastern and eastern part of the country, in the micro-regions located near the Slovak, Ukrainian and Romanian border. This coincides with case studies from Slovakia identifying rural and peripheral regions mainly in the proximity of the Hungarian, Ukrainian and Polish border. 


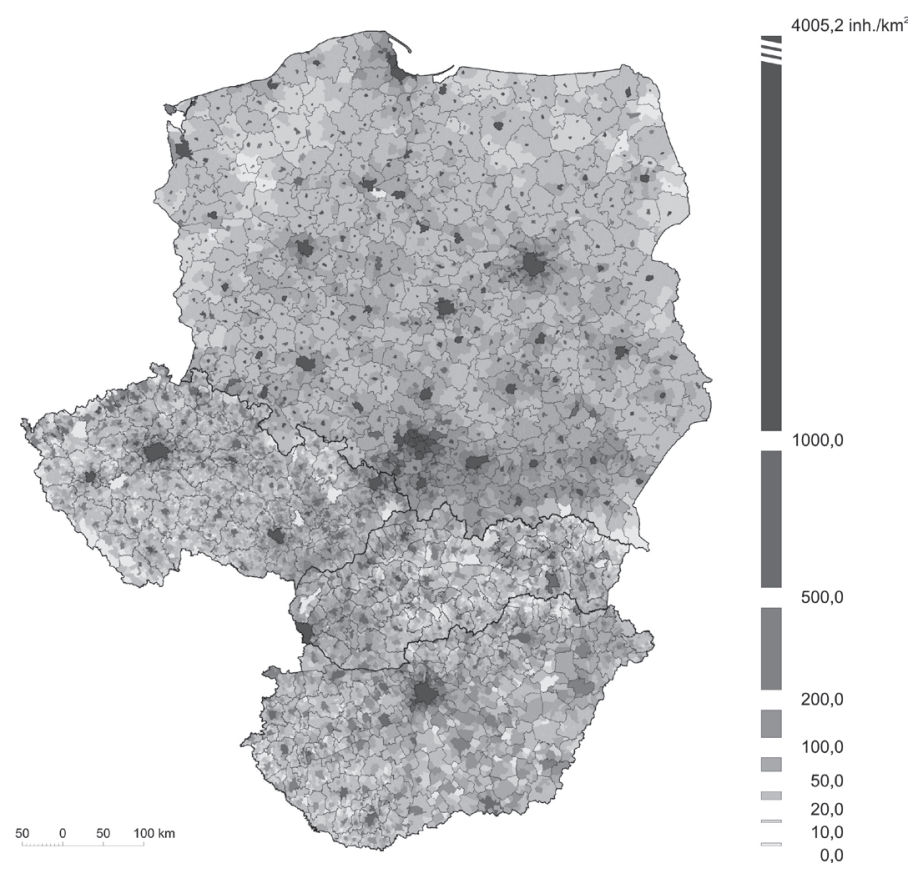

Fig. 2. Population density at the level of LAU 2 within Visegrad countries Source: designed by M. Mazur.

Over the past decade, new methodological approaches have emerged in the delineation of rural areas in Hungary, such as the method of spatial relation analysis which examines the rearrangements in the direction of population movement, and the spatial phenomena of mobility and commuting (Szörényiné 2007), or the questions of availability and accessibility (Lőcsei and Szalkai 2008). Studies dealing with social and economic problems and future perspectives of rural and peripheral areas represent new tendencies taking place in the research of rural areas (Fekete Éva 2005, 2013; Nagy 2013, Nagy-Koós 2014).

Also Czech geographers are aware of the heterogeneous character of rural areas, therefore some have suggested typologies of rural space based on various approaches. Perlín et al. (2010) have created a typology of rural space in Czechia based on a synthesis of 16 statistical indicators. They have defined 8 types of Czech rural space ranging from developed suburban rural areas to peripheral rural areas. Hruška (2014b) delimited five basic types of rural localities on the example of the Moravian-Silesian Region on the basis of a specific constellation construction of processes and actors, which was distinctive for such a locality. The methodology of his work relied on qualitative interviews with rural actors and analysis of articles from newspapers.

In contrast to success areas, there are problem areas often identified within peripheral areas in Polish geography. Understood in such a way the problem areas might be seen as a parallel to the marginal areas or underexposed areas used in Slovak geography (see Novotný et al. 2015). A problem area represents a spatial unit with a concentration of negative social, economic and/or environmental phenomena. There are also other similar terms, e.g. areas of conflict, of shortage, of depression, of production reserves or underdeveloped areas (Bański 1999).All these negative features of a given area can result 


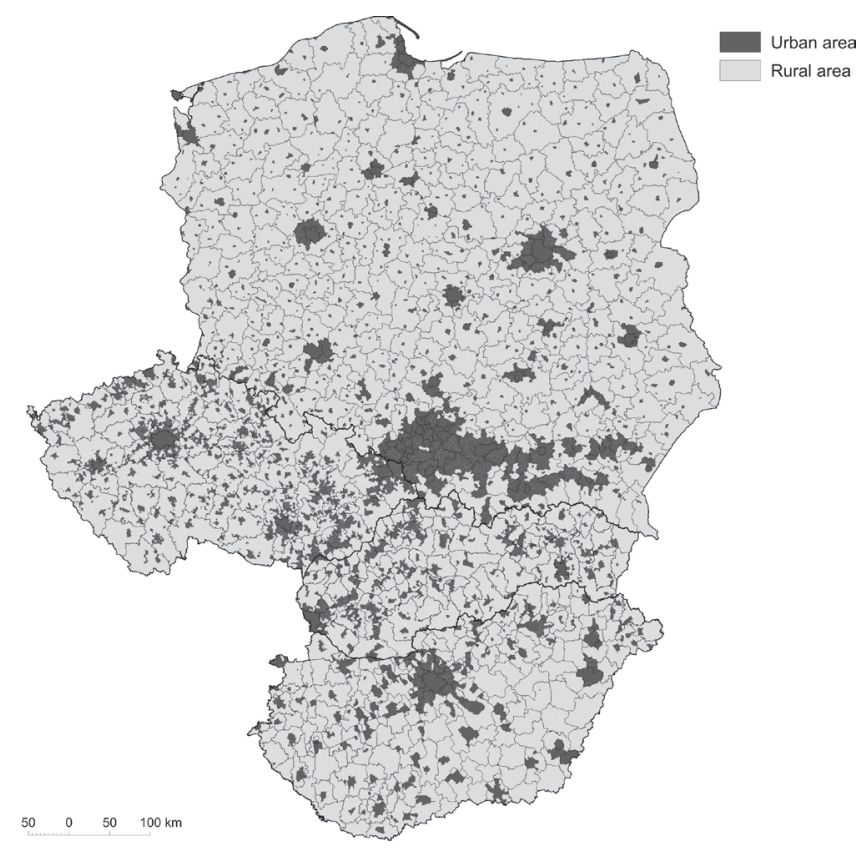

Fig. 3. Urban and rural LAU 2 in Visegrad countries by the population density ${ }^{5}$ Source: designed by M. Mazur.

from an unfavourable location but they may not. Three types of such areas were studied most often by Polish geographers: areas of ecological danger, areas with demographic problems and agricultural problem areas. Research into the first subject was carried out especially during the 1970s and 1980s, when polluting emissions were much higher and less controlled than currently (Kassenberg and Rolewicz 1984; Rola-Kunach 1984; GUS 1992). According to these research papers, rural problem areas can also be identified as distinct from peripheral ones. Although areas with demographic problems (Jelonek 1986; Eberhardt 1989; Bański 2002; Bański and Mazur 2009) and agricultural problem areas (Kulikowski 1992, 2003; Bański 1999; Rosner 1999) usually co-exist with peripheries and stimulate each other, there are also some exceptions identified in this matter because the genesis of them can be something other than distant location, e.g. structural or historical. Also certain specific types of problem area sometimes used to be identified, for instance so called areas of conflict. They result from a shortage of space and competition between different functions. They are identified by the circumstances of the advantage of demand for certain assets of given space over its supply. They are also identified rather in suburban zones than in peripheral areas.

Such a distinction between a peripheral (unfavourable) location itself and its potential consequences is commonly used in Polish geography. Kukliński (1980) relates the strengths and weaknesses of different regions according to three approaches: 1) quantitative, 2) economic effectiveness and 3) quality of life. In the quantitative approach, regions are categorized on the basis of their total potential (e.g. production measure, labour force or

\footnotetext{
${ }^{5}$ All communities with a population density lower than the average of the whole Visegrad area are considered to be rural, others to be urban.
} 
population size). In the second approach regions are categorized on the basis of economic indicators and in the third approach on the basis of the impact of the economy on the quality of life. Gorzelak (1989) proposes the classification of regions strictly according to relations between their level and dynamics of development in comparison to national average values, also regardless of their location. According to him, rural areas should simply overcome more barriers to achieve the success due to their unfavourable location in relations to cities (Gorzelak 2003). Bański (2008) distinguishes three groups of rural areas of success: 1) local centres of success, 2) rural areas of progression and 3) areas of competitive agriculture. There are numerous conditions determining the potential success of peripheries. Together with location, an equally important role is played by social, economic, and technical and organizational conditions.

\section{Summary}

There are many definitions of rural and peripheral areas based on various epistemological traditions and it is impossible to say which one is right. Instead, their appropriateness should be assessed according to the context, in which they are used. Therefore, similarly as Shortall and Warner (2012) suggest in their introductory chapter for the book of Shucksmith et al. (2012), it is not necessary to use only one definition of rural. Instead, each article uses its own conceptualization of rural and peripheral which best fits to its purpose.

Therefore the functional definitions serve as the main point of departure for the investigation carried out within this article, as this large-scale study is based mainly on quantitative data. The population criterion derived from the functional definition of rural is also used in for case study companies selection in the paper by Egedy et al. (2015), as the location of that enterprenuerships in a rural municipality was the crucial criterion. The political-economic approach is used by Kovács et al. (2015) as it is sufficiently sensitive to spatial unevenness in the distribution of various sources of capital - financial, human and social. Moreover, such an approach arose out of the criticism of capitalism and neoliberal modes of regulation, which are more or less adopted by all Visegrad countries. Therefore, it allows a reaction to its insufficiencies reflecting in spatial unevenness. The definition of rural as social representation is useful for detail analysis of individual rural enterprises in order to reveal traces of rural distinctiveness in the business owners' behaviour.

The results presented in this article are partially outcome of the project VEGA 1/0473/14: Dynamic 3-D modelling of urban landscape with a multiscale approach. The preparation of this article was also supported by a grant from the Hungarian Scientific Research Fund (OTKA) Grant Agreement no. K 105534. 


\section{References}

Bański J., 1999, Obszary problemowe w rolnictwie Polski, Prace Geograficzne, 172, Warszawa, IGiPZ PAN.

Bański J., 2002, Typy ludnościowych obszarów problemowych, [in:] Bański J., Rydz E. (eds), Społeczne problemy wsi, Studia Obszarów Wiejskich, 2, pp. 41-52.

Bański J., 2008, Wiejskie obszary sukcesu gospodarczego, Studia Obszarów Wiejskich, 14.

Bański J., (ed), 2015, Rural Atlas of Poland, in print.

Bański J., Mazur M., 2009, Identyfikacja obszarów o silnej koncentracji problemów społecznych, [in:] J. Bański (ed), Analiza zróżnicowania i perspektyw rozwoju obszarów wiejskich w Polsce do 2015 roku, Studia Obszarów Wiejskich, 16, pp. 79-96.

Barta G., Beluszky P., Berényi I., 1975, A hátrányos helyzetü területek vizsgálata Borsod-Abaúj-Zemplén megyében, Földrajzi Értesítő (Hungarian Geographical Bulletin), 24, pp. 299-390.

Beluszky P., 1965, Falusi településeink osztályozása (Classification of Hungarian villages), Földrajzi Értesítő (Hungarian Geographical Bulletin), 14, pp. 149-165.

Beluszky P., Sikos T. T., 1983, Typology of rural settlements in Hungary (settlement morphological processes in the rural areas of the country), Hungarian Academy of Sciences, Geographical Research Institute.

Bosworth G., 2012, Characterising rural businesses - Tales from the paperman, Journal of Rural Studies, 28, pp. 499-506.

Cloke P., 2006, Conceptualizing Rurality, [in:] Cloke P., Marsden T., Mooney P. (eds), Handbook of Rural Studies, SAGE, London, pp. 18-28.

Cloke P., Goodwin M., 1992, Conceptualizing Countryside Change: from Post-fordism to Rural Structured Coherence, Transactions of the Institute of British Geographers, 17, pp. 321-336.

Csatári B., 2000, A magyarországi kistérségek vidékiség-kritériumai, [in:] Horváth Gy., Rechnitzer J. (eds), Magyarország területi szerkezete és folyamatai az ezredfordulón, MTA Regionális Kutatások Központja, Budapest, pp. 193-217.

Csatári B., 2005, Criteria of rurality for the Hungarian micro-regions: Major problems facing rural areas in Hungary, [in:] Barta, Gy. et al. (eds), Hungarian Spaces and Places: Patterns of Transition, Pécs, Centre for Regional Studies of the Hungarian Academy of Sciences, pp. 466-482.

Dorgai L., 1998, Néhány gondolat a "MI tekinthető vidéknek?", Gazdálkodás, 42, pp. 60-64.

Eberhardt P., 1989, Regiony wyludniajqce się w Polsce, Prace Geograficzne, 148, IGiPZ PAN, Warszawa.

Egedy T., Cerić D., Konopski M., Kučerová S., Kulla M., Nestorová-Dická J., Svobodová R., 2015, Entrepreneurship as a potential driving force for the further development of rural areas-good examples from Visegrad countries, Studia Obszarów Wiejskich, 39, pp. 103-128.

Enyedi G., 1977, A falusi életkörülmények területi típusai Magyarországon (Regional types of rural living conditions in Hungary), Földrajzi Értesítő (Hungarian Geographical Bulletin), 26, pp. 67-85.

Erdei F., 1974, A magyar falu (The Hungarian village), Akadémiai Kiadó, Budapest (Reprint).

Fáziková M. et al., 2003, Súčasné problémy rozvoja vidieckeho priestoru na Slovensku: výskumná správa, Slovak University of Agriculture, Nitra.

Fekete Éva G., 2005, Long-term unemployment and its alleviation in rural areas: case of Hungary, Centre for Regional Studies of Hungarian Academy of Sciences, Pécs.

Fekete Éva G., 2013, Foglalkoztatás-bővités a helyi elsődleges munkaerőpiacon, Észak-magyarországi.

Gorzelak G., 1989, Rozwój regionalny Polski w warunkach kryzysu i reformy, Rozwój regionalny - Rozwój lokalny - Samorząd terytorialny, 14, Instytut Gospodarki Przestrzennej WGiSR UW, Warszawa. 
Gorzelak G., 2003, Bieda i zamożność regionów, [in:] Sagan I., Rzepczyński M. (eds), Wymiar i wspótczesne interpretacje regionu, Katedra Geografii Ekonomicznej UG, Gdańsk, pp. 57-77.

GUS, 1992, Obszary ekologicznego zagrożenia w Polsce w latach 1982 i 1990, Studia i analizy statystyczne, Warszawa, GUS.

Halfacree K., 1993, Locality and Social Representation: Space, Discourse and Alternative Definitions of the Rural, Journal of Rural Studies, 9, pp. 23-37.

Hoggart K., 1990, Let's Do Away with Rural, Journal of Rural Studies, 6, pp. 245-257.

Hruška V., 2014a, Proměny př́stupů ke konceptualizaci venkovského prostoru v rurálních studiích, Sociologický časopis/Czech Sociological Review, 50, pp. 581-601.

Hruška V., 2014b, Rural Studies and Uneven Development of Rural Areas in Central Europe, [in:] Koutský J., Raška P., Dostál P., Herrschel T. (eds.), Transitions in regional science - regions in transition: Regional research in Central Europe, Wolters Kluwer, Prague, pp. 52-70.

Jelonek A., 1986, Obszary zagrożeń demograficznych, Folia Geographica, Seria Geographica-Oeconomica, 19, pp. 33-49.

Kassenberg A., Rolewicz C., 1984, Obszary ekologicznego zagrożenia (wstępna diagnoza przestrzenna-1980 r.), Gospodarka zasobami przyrody, Studia KPZK PAN 85, Warszawa, pp. 150-155.

Kiełczewska-Zaleska M., 1972, Geografia osadnictwa, PWN, Warszawa.

Kostrowicki J., 1976, Obszary wiejskie jako przestrzeń wielofunkcyjna, Zagadnienia badawcze i planistyczne, Przegląd Geograficzny, 48, pp. 601-611.

Kovács Z., Csachová S., Ferenc M., Hruška V., Konopski M., 2015, Development policies on rural peripheral areas in Visegrad countries: a comparative policy analysis, Studia Obszarów Wiejskich, 39, pp. 77-102.

Kukliński A., 1980, Gospodarka przestrzenna i studia regionalne, Biuletyn KPZK PAN, 111, Warszawa.

Kulikowski R., 1992, Obszary problemowe rolnictwa w Polsce, [in:] Wybrane zagadnienia obszarów wiejskich, Biuletyn KPZK PAN 158, Warszawa, pp. 23-40.

Kulikowski R., 2003, Obszary problemowe rolnictwa w Polsce, [in:] A. Ciołkosz (ed), Charakterystyka rolniczej przestrzeni produkcyjnej Polski, GUS, Warszawa, pp. 179-186.

Kulcsár V. (ed), 1976, A változó falu (The changing village), Gondolat Kiadó, Budapest.

Lettrich E., 1976, Faluhálózatunk fö vonásai (Main characteristics of the Hungarian village network), Földrajzi Értesítő (Hungarian Geographical Bulletin), 25, pp. 319-324.

Lőcsei H., Szalkai G., 2008, Helyzeti és fejlettségi centrum-periféria relációk a hazai kistérségekben (Locational and development centre-periphery relations in the Hungarian micro-regions), Területi Statisztika, 11, pp. 305-314.

Mormont M., 1990, Who is Rural? Or, How to Be Rural: Towards a Sociology of the Rural, [in:] Marsden T., Whatmore S., Lowe P., Rural Restructuring: Global Processes and their Responses, David Fulton Publishers, London.

Moseley M., 1980, Rural Development and its Relevance to the Inner City Debate, Inner Cities Working Party Paper, Social Science Research Council, London.

MRD, 2012, National Rural Strategy of Hungary 2012-2020, Ministry of Rural Development, Budapest.

MRRW, 2014, Program Rozwoju Obszarów Wiejskich na lata 2014-2020 (National Rural Development Program), Ministerstwo Rolnictwa i Rozwoju Wsi, Warszawa.

Murdoch J., Marsden T., 1994, Reconstituting Rurality: Class, Community, and Power in the Development Process, UCL Press, London.

Nagy E., 2013, "Borderless" strategies and the changing rural-urban relationship: motives of subrubanisation at the Hungarian-Romanian border, Settlement Geographical Studies, 2, pp. 32-51. 
Nagy G., Koós B., 2014, First results in modelling objective well-being in Hungary at lower territorial level, Területi Statisztika (Spatial Statistics), 4 (2), pp. 71-86.

NHRDP, 2007, New Hungary Rural Development Programme 2007-2013, Budapest.

OECD, 2011, OECD Regional Typology, OECD - Directorate for Public Governance and Territorial Development, [cit. 2015-04-28]: URL: http://www.oecd.org/gov/regional-policy/OECD_regional_typology_Nov2012.pdf.

Novotný L., Mazur M., Egedy T., 2015, Definition and delimitation of peripheries of Visegrad countries, Studia Obszarów Wiejskich, 39, pp. 35-48.

Perlín R., Kučerová S., Kučera Z., 2010, Typologie venkovského prostoru Česka, Geografie, 115, pp. 161-187.

Rola-Kunach S., 1984, Obszary ekologicznego zagrożenia w Polsce w 1982 r. Zagrożenie i ochrona środowiska. Woda i powietrze, Wiadomości Statystyczne, 275 (5), pp. 32-35.

Rosner A., 1999, Typologia wiejskich obszarów problemowych, Problemy Rozwoju Wsi i Rolnictwa, IRWiR PAN, Warszawa.

Shortall S., Warner M., 2012, Rural Transformations: Conceptual and Policy Issues, [in:] Shucksmith M., et al. (eds), Rural transformations and rural policies in the US and UK, Routledge, New York, pp. 3-17.

Shucksmith M., et al. (eds), 2012, Rural transformations and rural policies in the US and UK, Routledge, New York.

Smallbone D., 2005, Fostering Entrepreneurship in rural areas, OECD. [cit. 2015-01-29]: URL: http:// www.oecd.org/site/cfecpr/42203059.pdf.

Szörényiné K. I., 2007, Relation analysis in rural space: a research method for exploring the spatial structure in Hungary, Centre for Regional Studies of Hungarian Academy of Sciences, Pécs.

Szulc H., 1976, O typologiach morfologicznych osiedli wiejskich w Polsce, Przegląd Geograficzny, 48, pp. 627-636.

Woods M., 2005, Rural geography: Processes, Responses and Experiences in Rural Restructuring, SAGE, London.

Woods M., 2011, Rural, Routledge, London. 
http://rcin.org.pl 